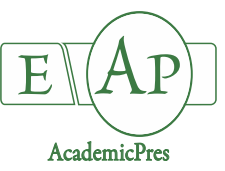

San Martín-Hernández C, Gómez-Merino FC et al. (2021)

Notulae Botanicae Horti Agrobotanici Cluj-Napoca

Volume 49, Issue 2, Article number 12320

DOI: $10.15835 /$ nbha 49212320

Research Article

\title{
Nitrogen and potassium supplied by phenological stages affect the carotenoid and nutritive content of the tomato fruit
}

\author{
Cesar SAN MARTÍN-HERNÁNDEZ ${ }^{\text {la }}$, Fernando C. GÓMEZ- \\ MERINO $^{1 \mathrm{~b}}$, Crescenciano SAUCEDO-VELOZ ${ }^{1}$, Eber A. QUINTANA- \\ OBREGÓN² ${ }^{2}$ María D. MUY-RANGEL ${ }^{3}$, Libia I. TREJO-TÉLLEZ ${ }^{1 *}$
}

\author{
${ }^{1}$ College of Postgraduates in Agricultural Sciences Campus Montecillo. Montecillo, State of Mexico, Mexico; \\ sanmartin.cesar@colpos.mx; fernandg@colpos.mx; sauveloz@colpos.mx; tlibia@colpos.mx (*corresponding author) \\ ${ }^{2}$ CONACYT-Centro de Investigación en Alimentación y Desarrollo, A.C. Coordinación Tecnología de Alimentos \\ de Origen Vegetal. Hermosillo, Sonora, Mexico; eber:quintana@ciad.mx \\ ${ }^{3}$ Centro de Investigación en Alimentación y Desarrollo, A.C. Coordinación Culiacán. Culiacán de Rosales, Sinaloa, \\ Mexico;mdmuy@ciad.mx \\ ${ }^{a, b}$ These authors contributed equally to the work
}

\begin{abstract}
The effect of nitrogen $(\mathrm{N})$ and potassium $(\mathrm{K})$ supply by phenological stages of horticultural crops such as tomato has been little explored so far. In this study, we evaluated the impact of $\mathrm{N}$ supply in the vegetative stage and $\mathrm{K}$ in the reproductive stage of tomato, on the carotenoid and nutritive content of fruits of three truss clusters. The concentrations of protein, lycopene, $\beta$-carotene, sugars, vitamin $\mathrm{C}$ and fruit juice were affected by the $\mathrm{N}$ and $\mathrm{K}$ application by phenological stages, although the $\mathrm{N} \times \mathrm{K}$ interaction was not significant in the last three variables. Increases in $\mathrm{N}$ from 10 to $16 \mathrm{~mol}_{\mathrm{c}} \mathrm{m}^{-3}$ of nutrient solution (NS) in the vegetative stage of the crop increased the concentrations of protein, vitamin C, sugars (temporarily) and fruit juice. Likewise, increases in potassium ( 5 to $13 \mathrm{~mol}_{\mathrm{c}} \mathrm{m}^{-3} \mathrm{NS}$ ) in the reproductive stage of the crop raised the concentrations of sugars, vitamin $\mathrm{C}$, protein, lycopene, $\beta$-carotene and fruit juice. The concentration of carotenoids and the nutritional value of the tomato fruit were influenced by $\mathrm{N}$ and $\mathrm{K}$ nutrition by phenological stages, and these effects change slightly depending on the cluster harvested and the temperature during the growing cycle.
\end{abstract}

Keywords: $\beta$-carotene; lycopene; protein; Solanum lycopersicum L.; sugars; vitamin C

\section{Introduction}

The per capita intake of tomatoes in the world went from $8 \mathrm{~kg}$ to $21 \mathrm{~kg}$ between 1961 and 2013 (FAO, 2018). Tomato fruit is a source of proteins, vitamins, carotenoids, carbohydrates, and antioxidant substances, among others (Yilmaz, 2001; Bhowmik et al., 2012; Souri and Dehnavard, 2017; Souri and Dehnavard, 2018). Tomato is a significant source of dietary vitamin $\mathrm{C}$ and in a daily intake, it can supply $47 \%$ of vitamin C (Jones, 2008). Among the carotenoids, lycopene helps reduce the risk of cancer, osteoporosis, and cardiovascular diseases (Burton-Freeman and Reimers, 2011), while $\beta$-carotene shows provitamin A activity (Tang, 2010).

Received: 28 Mar 2021. Received in revised form: 18 May 2021. Accepted: 28 May 2021. Published online: 23 Jun 2021.

From Volume 49, Issue 1, 2021, Notulae Botanicae Horti Agrobotanici Cluj-Napoca journal uses article numbers in place of the traditional method of continuous pagination through the volume. The journal will continue to appear quarterly, as before, with four annual numbers. 
Tomato pulp and juice represent an important source of nutraceutical compounds, albeit the concentration of such compounds may be significantly affected by factors such as the genotype (Prudent et al., 2009), environment (Cebolla-Cornejo et al., 2011), and nutrient supply (Arah et al., 2015). The ratios between sugars and organic acids give the tomatoes special tastes, although the role of genotype and environment cannot be ignored (Beckles, 2012; Souri and Dehnavard, 2017; Souri et al., 2017). Sugars are the major constituents and influence the taste and quality of tomato (Beckles, 2012). Proteins, as the major organic form of nitrogen, are important in foodstuffs (NNDSR, 2018).

Nitrogen $(\mathrm{N})$ and potassium $(\mathrm{K})$ are the most required elements for plant metabolism, with 1 to $6 \%$ of the dry matter composition (Hawkesford et al., 2012; Souri and Hatamian, 2019). N is part of proteins, nucleic acids, coenzymes, chlorophyll, and other compounds that affect the physiological and biochemical processes of plants (Leghary et al., 2016). Application of potassium $(\mathrm{K})$ and nitrogen $(\mathrm{N})$ can significantly influence tomato plant growth, yield and quality parameters (Dehnavard et al., 2017; Mardanluo et al., 2018). By increasing the dose of $\mathrm{N}$ from 0 to 120 and $180 \mathrm{~kg} \mathrm{ha}^{-1}$ during cultivation, sugars, lycopene, protein, and vitamin $\mathrm{C}$ concentrations in tomato fruit are increased (Kuscu et al., 2014; Hui et al., 2017). However, decreases in the contents of lycopene, $\beta$-carotene, and vitamin $\mathrm{C}$ in tomato fruits have also been reported when increasing $\mathrm{N}$ fertilization (Dorais et al., 2008; Wang et al., 2015).

Potassium $(\mathrm{K})$ has key roles in various physiological and biochemical processes in plants, including photosynthesis, osmoregulation, enzyme activity, secondary metabolism, protein biosynthesis, sugar transport and many quality traits of products (Oosterhuis et al., 2014; Pourranjbari Saghaiesh et al., 2018; Tohidloo et al., 2018). Likewise, in open field tomato cultivation, $\mathrm{K}$ doses from 0 to 60 and $120 \mathrm{~kg} \mathrm{ha}^{-1}$, or K levels of 200 to $400 \mathrm{mg} \mathrm{L}^{-1}$ in the hydroponic solution, increase the content of vitamin $\mathrm{C}$, sugars, lycopene, and protein of the fruit (Almeselmani et al., 2009; Ahmad et al., 2015), although decreases in sugars (42 to $25 \mathrm{~g}$ ) and vitamin $\mathrm{C}$ were also reported due to a $\mathrm{K}$ supply of 0 to $200 \mathrm{~kg} \mathrm{ha}^{-1}$ (Ehsan-Akhtar et al., 2010). Until now, individual fertilizations of $\mathrm{N}$ and $\mathrm{K}$, along with combinations of the two nutrients, have been evaluated in tomato. Nonetheless, nutritional requirements of $\mathrm{N}$ and $\mathrm{K}$ vary according to the phenological stage (Jones, 2008). Furthermore, fruit quality also varies among clusters (Coyago-Cruz et al., 2018).

Tomato mineral nutrition has been extensively studied for many years, though little attention has been paid to $\mathrm{N}$ and $\mathrm{K}$ nutrition from a phenological point of view. In this study, we hypothesized that $\mathrm{N}$ and $\mathrm{K}$ nutrition by phenological stages may affect the nutritional value of tomato fruit. Thus, we aimed to study the impact that the supply of $\mathrm{N}$ during the vegetative stage and of $\mathrm{K}$ during the reproductive stage of tomato have on the concentration of carotenoids and the nutritional value of the fruit in three clusters.

\section{Materials and Methods}

\section{Plant material, treatments and experimental design}

The research was done in hydroponics using 'tezontle' (red volcanic rock, particles $\leq 12 \mathrm{~mm}$ in diameter) as substrate, under greenhouse conditions, with 37-day-old tomato cv. 'Charleston' (Rogers Seeds ${ }^{\circ}$ ) seedlings. The experiment was carried out in Montecillo, Mexico. The complete experiment was carried out for six months (July to December). In the nutrient solution (NS) of the hydroponic culture, two nutrients were evaluated by phenological stages. In the vegetative stage (limited to the anthesis of the first flower cluster) corresponding to the first 45 days after transplantation (dat), $\mathrm{N}$ was supplied at concentrations of 10, 12, 14, and $16 \mathrm{~mol}_{\mathrm{c}} \mathrm{m}^{-3} \mathrm{NS}$, applying $75 \%$ as $\mathrm{NO}_{3}{ }^{-}$and $25 \%$ as $\mathrm{NH}_{4}{ }^{+}$; and in the reproductive stage (46 to 170 dat), $\mathrm{K}$ levels of $5,7,9,11$, and $13 \mathrm{~mol}_{\mathrm{c}} \mathrm{m}^{-3} \mathrm{NS}$ were evaluated. The experiment was carried out under a factorial arrangement in a completely randomized split-plot design, with $\mathrm{N}$ as a large plot and $\mathrm{K}$ as a small plot, resulting in 20 treatments with six replicates. The experimental unit (EU) was one plant per pot with $13 \mathrm{~L}$ of 'tezontle.'

According to the phenological stage, each experimental unit was irrigated with Steiner's nutrient solution (Steiner, 1961) modified in $\mathrm{N}$ and $\mathrm{K}$. The original concentrations of $\mathrm{NO}_{3}^{-}$and $\mathrm{K}^{+}$in Steiner's solution 
is 12 and $7 \mathrm{~mol}_{\mathrm{c}} \mathrm{m}^{-3} \mathrm{NS}$, respectively. In the first 30 dat, eight irrigations of 5 min each were applied daily at 1 $\mathrm{h}$ intervals using $4 \mathrm{~L} \mathrm{~h}^{-1}$ droppers. After this and until the conclusion of the harvest (167 dat), 16 daily irrigations were applied in the abovementioned manner.

The maximum and minimum temperatures during the research were recorded with a $\mathrm{Hobo}^{\circ} \mathrm{H} 8$ data logger (Onset Computer Corporation, USA), reporting the values as decennial averages from July to December (Figure 1).

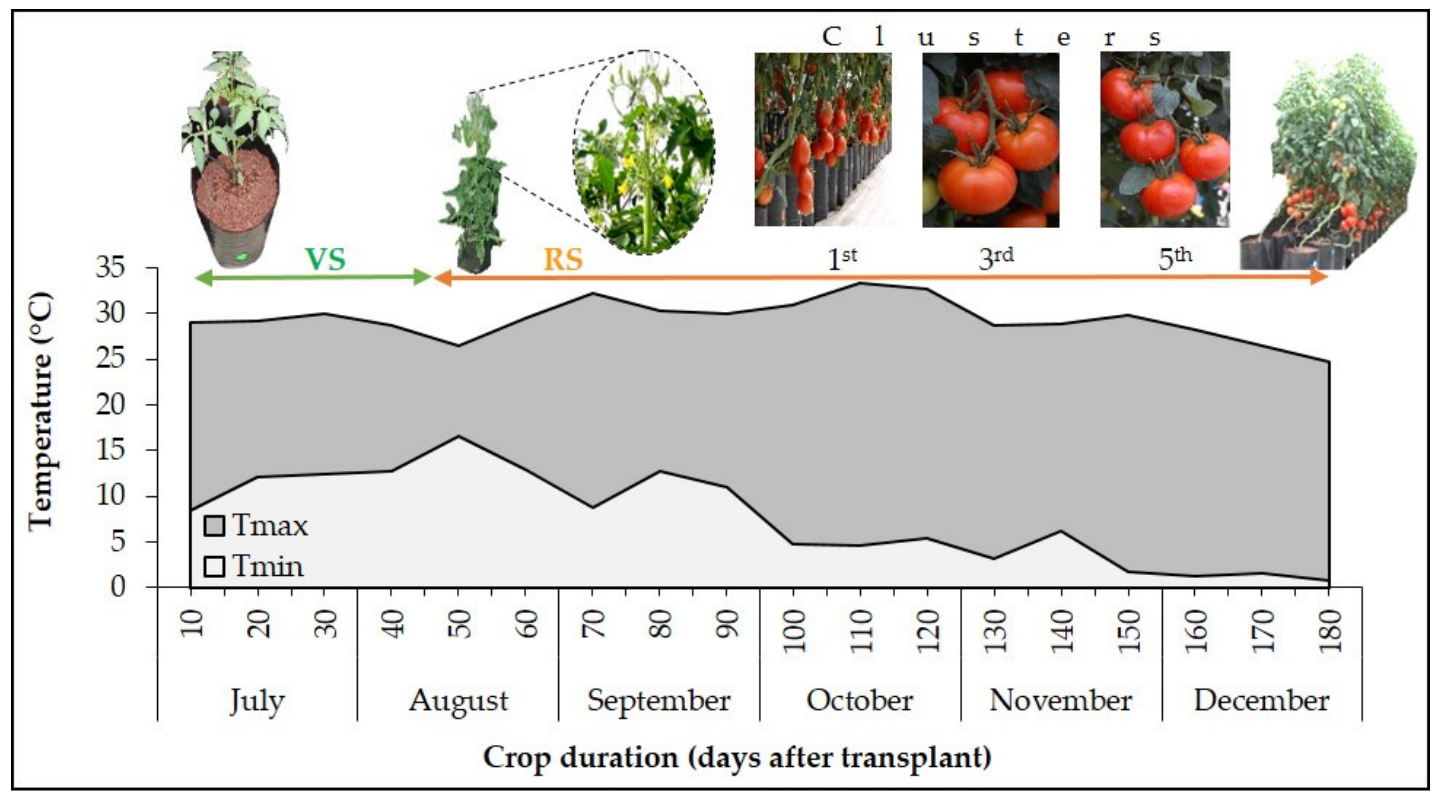

Figure 1. Decennial averages of maximum and minimum temperatures during the vegetative (VS) and reproductive (RS) stages of the tomato crop from July to December

\section{Evaluated variables}

The variables were analysed in completely red fruits taken individually from the first (110 dat), third (131 dat), and fifth (167 dat) floral clusters (see details in Figure 1), considering two fruits per experimental unit and per cluster.

Juice. The juice was obtained with an extractor (Tur Mix, Mexico) considering the initial fruit weight and the final weight of the extracted juice (without seeds or epidermis), expressing the value as a percentage (San Martín-Hernández et al., 2012).

Total sugars in tomato juice. The determination of total sugars was done from $1 \mathrm{~g}$ of juice by means of the anthrone colorimetric method (Witham et al., 1971) and by using a D-glucose standard (Sigma-Aldrich", USA) of known concentration in the calibration curve. The samples were read at $600 \mathrm{~nm}$ in a spectrophotometer (Spectronic 20 Baush and Lomb', USA), obtaining the value in $\mathrm{g} \mathrm{kg}^{-1}$ of fresh fruit (FF).

Vitamin C. Vitamin C was determined based on the 967.21 official method (AOAC, 2002). One millilitre of tomato juice was mixed with $30 \mathrm{~mL} 0.5 \%$ oxalic acid; then, a $5 \mathrm{~mL}$ aliquot was collected and titrated with Tillman's solution (2,6-dichlorophenol indophenol 0.02\%, DCIP from Sigma-Aldrich ${ }^{\circ}$ ) until colour change to pale pink (i.e. $15 \mathrm{~s}$ after the start of the reaction). The quantification of vitamin $\mathrm{C}$ was done by means of L-ascorbic acid standard (Sigma-Aldrich ${ }^{\circ}$, USA) in the calibration curve, expressing its concentration in $\mathrm{mg}$ $\mathrm{kg}^{-1} \mathrm{FF}$.

Protein. The concentration of $\mathrm{N}$ in the fruit was analysed using the micro Kjeldahl method and the percentage of $\mathrm{N}$ was converted to crude protein by multiplying the percentage of $\mathrm{N}$ by 6.63 , expressing the value in $\mathrm{g} \mathrm{kg}^{-1} \mathrm{FF}$ (Fujihara et al., 2001; AOAC, 2002). 
Lycopene and $\beta$-carotene. The carotenoids were extracted following the methods described by Lin and Chen (2003) with some modifications. Two grams of fresh fruit were ground for $1 \mathrm{~min}$ in a low volume blender, with $10 \mathrm{~mL}$ of extraction solvent (ethanol:hexane, 4:3, v/v), $0.05 \mathrm{~g} \mathrm{MgCO}_{3}$, and $1 \mathrm{~mL}$ butylated hydroxytoluene (BHT) at $0.025 \%$. The sample was shaken $30 \mathrm{~min}$ at $140 \mathrm{rpm}$ on an orbital shaker (Lab-Line', USA) under reduced light conditions. The upper phase was transferred to a $125 \mathrm{~mL}$ flask and the lower phase was extracted again with $16 \mathrm{~mL}$ of extraction solvent, shaking as in the previous step. The upper phase was transferred to the same $125 \mathrm{~mL}$ flask and the lower part was re-extracted with $5 \mathrm{~mL}$ of hexane at $280 \mathrm{rpm}$ for $20 \mathrm{~min}$. In this last step, the sample was filtered with Whatman No. 1 paper, placing the extract in the same $125 \mathrm{~mL}$ flask, to which $37.5 \mathrm{~mL}$ of distilled water and $25 \mathrm{~mL}$ of $10 \% \mathrm{NaCl}$ were added for a phase partition. The organic phase was collected and evaporated to dryness at $35^{\circ} \mathrm{C}$. The sample was re-suspended with $\mathrm{CH}_{2} \mathrm{Cl}_{2}$ and filtered on a $0.45 \mu \mathrm{m}$ membrane, obtaining a final volume of $1 \mathrm{~mL}$ of extract, which was placed in an amber vial for storage at $-20^{\circ} \mathrm{C}$ until analysis by HPLC. The identification of carotenoids was done by comparison of the retention times with the authentic reference standards, which were subjected to a spectral scan. Lycopene showed three absorbance maximums at 448, 508, and $472 \mathrm{~nm}$ (Figure 2A), and $\beta$-carotene showed two at 456 and $480 \mathrm{~nm}$ (Figure 2B). However, in this work the HPLC analysis per se was favourable for both compounds at $472 \mathrm{~nm}$ (Figure 2C). For these two variables, three replicates were analysed in duplicate in each treatment, quantifying $\mathrm{mg} \mathrm{kg}^{-1} \mathrm{FF}$ according to the calibration curve at concentrations of 10, 30, 100, 200, 300, and 400 $\mu \mathrm{g} \mathrm{mL} \mathrm{L}^{-1}$ in lycopene (Abs $=145.086^{*}\left[\right.$ lycopene $\left.\left.\mu \mathrm{g} \mathrm{mL}^{-1}\right]+1466.630, \mathrm{R}^{2}=0.996\right)$, and $0.5,1.0,2.0,4.0,30.0$, and $60 \mu \mathrm{g} \mathrm{mL} L^{-1}$ for $\beta$-carotene $\left(A b s=62.969^{*}\left[\beta\right.\right.$-carotene $\left.\left.\mu \mathrm{g} \mathrm{mL}^{-1}\right]+30.385, \mathrm{R}^{2}=0.987\right)$.

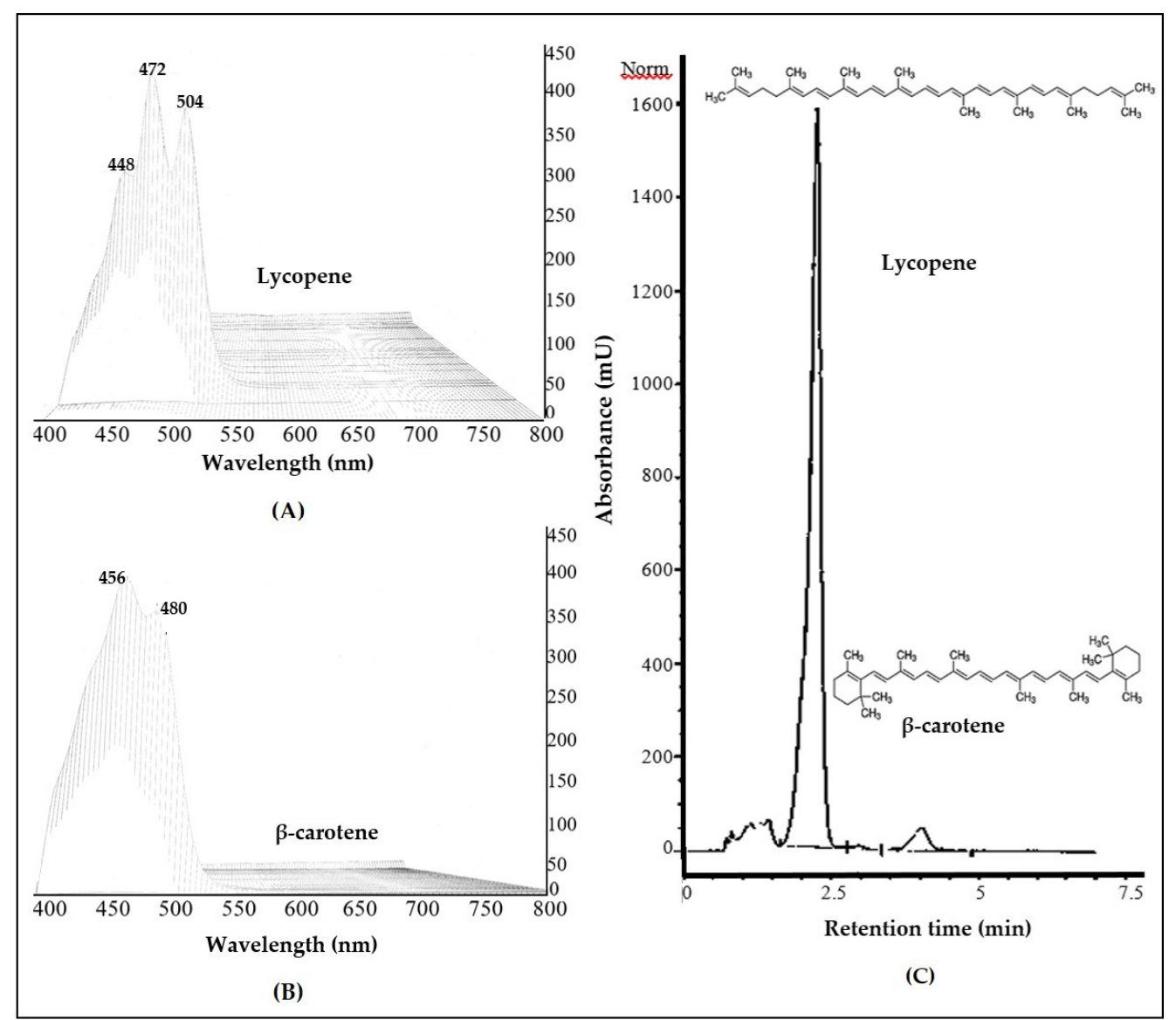

Figure 2. Spectral scanning of carotenoids (A and B); lycopene and $\beta$-carotene analyzed by HPLC in completely red tomato fruits (C) 
The samples were analysed with the butanol, acetonitrile, and dichloromethane mobile phase in the ratio 29.7:69.3:1 (v:v:v) according to Lin and Chen (2003). The elution was in isocratic mode, injecting $20 \mu \mathrm{L}$ sample ${ }^{-1}$ at a flow of $2 \mathrm{~mL} \mathrm{~min}^{-1}$ and a duration of $7 \mathrm{~min}$ each. The carotenoids were analysed with an Agilent 1200 HPLC system (Germany) with a diode array detector and a Zorbax Eclipse XDB-C18 4.6x150 mm, 5 $\mu \mathrm{m} \varnothing$ column (USKH0637359); the solvents ethanol (Fermont', Mexico), hexane (J.T. Baker, Mexico), methylene chloride, 1-butanol, and the lycopene and $\beta$-carotene standards (Sigma-Aldrich ${ }^{\circ}$, USA) were HPLC grade.

\section{Statistical analysis}

The statistical analysis was done based on the effects model (1) (Kuehl, 2000; Jones and Nachtsheim, 2009) adapted to a completely randomized split-plot design.

$$
Y_{i j k}=\mu+N_{i}+\varepsilon_{a}+K_{j}+N \times K_{i j}+\varepsilon_{i j k}
$$

Where: $\mathrm{Y}_{\mathrm{ijk}}=$ response variable; $\mu=$ general mean; $\mathrm{N}_{\mathrm{i}}=$ effect of the $\mathrm{i}$-th level of $\mathrm{N} ; \varepsilon_{\mathrm{a}}=$ large plot experimental error; $\mathrm{K}_{\mathrm{j}}=$ effect of the $\mathrm{j}$-th level of $\mathrm{K} ; \mathrm{N} \times \mathrm{K}_{\mathrm{ij}}=$ effect of the $\mathrm{N} \times \mathrm{K}$ interaction; $\mathcal{E}_{\mathrm{ijk}}=$ random experimental error. $\varepsilon_{\mathrm{a}} \sim \mathrm{NI}\left(0 \sigma_{a}^{2}\right)$ and $\mathcal{E}_{\mathrm{ijk}} \sim \mathrm{NI}\left(0 \sigma^{2}\right)$ are the assumptions of the model that are assumed to be normal, independent, with zero mean, and common variance $\sigma^{2}$.

The variables determined in the fruits were analysed individually for each of the three clusters evaluated, because their behaviour can change among them (Coyago-Cruz et al., 2018). With the data, the analysis of variance was performed and the means were compared according to the Tukey test $(p \leq 0.05)$ considering the standard deviation (SD) with the SAS 9.3 software (SAS, 2011).

\section{Results and Discussion}

The main effect of $\mathrm{N}$ was significant in the concentrations of juice, sugars, and lycopene in fruits of the first cluster, in the concentrations of vitamin $\mathrm{C}$ and protein of fruits of the three clusters, and in the concentration of $\beta$-carotene of fruits of the first and third clusters analysed. The main effect of $\mathrm{K}$ was significant in all variables, except in the concentration of juice of the first cluster. On the other hand, the $\mathrm{N} \times \mathrm{K}$ interaction was only significant in the protein and lycopene concentrations of the first cluster and for $\beta$-carotene in the three clusters evaluated (Table 1 ).

Table 1. Effects (p-value) of the supply of $\mathrm{N}, \mathrm{K}$ and $\mathrm{N} \times \mathrm{K}$ interaction in tomato cultivation on the concentrations of total sugars, vitamin $\mathrm{C}$, protein, lycopene, $\beta$-carotene, and fruit juice

\begin{tabular}{|c|c|c|c|c|c|}
\hline \multirow{2}{*}{ Variable } & \multirow{2}{*}{ Cluster } & \multicolumn{3}{|c|}{ Source of variation } & \multirow{2}{*}{ Coefficient of variation (\%) } \\
\hline & & $\mathrm{N}$ & $\mathrm{K}$ & $\mathrm{N} \times \mathrm{K}$ & \\
\hline \multirow{3}{*}{ Juice } & 1 st & $0.0012 *$ & $0.1667 \mathrm{~ns}$ & $0.2401 \mathrm{~ns}$ & 4.7 \\
\hline & 3 rd & $0.3198 \mathrm{~ns}$ & $<.0001^{*}$ & $0.9973 \mathrm{~ns}$ & 2.6 \\
\hline & 5 th & $0.0956 \mathrm{~ns}$ & $0.0031^{*}$ & $0.9999 \mathrm{~ns}$ & 5.8 \\
\hline \multirow{3}{*}{ Total sugars } & 1st & $0.0040^{*}$ & $0.0190^{*}$ & $0.9288 \mathrm{~ns}$ & 13.2 \\
\hline & $3 \mathrm{rd}$ & $0.1469 \mathrm{~ns}$ & $0.0003^{*}$ & $0.9242 \mathrm{~ns}$ & 15.3 \\
\hline & 5 th & $0.3619 \mathrm{~ns}$ & $<.0001^{*}$ & $0.9986 \mathrm{~ns}$ & 12.5 \\
\hline \multirow{3}{*}{ Vitamin C } & 1 st & $<.0001^{*}$ & $<.0001^{*}$ & $0.8113 \mathrm{~ns}$ & 14.3 \\
\hline & $3 \mathrm{rd}$ & $0.0131^{*}$ & $<.0001^{*}$ & $0.0645 \mathrm{~ns}$ & 20.9 \\
\hline & 5th & $<.0001^{*}$ & $<.0001^{*}$ & $0.4058 \mathrm{~ns}$ & 15.7 \\
\hline \multirow{3}{*}{ Protein } & $1 \mathrm{st}$ & $<.0001^{*}$ & $<.0001^{*}$ & $<.0001^{*}$ & 14.0 \\
\hline & $3 \mathrm{rd}$ & $0.0065^{*}$ & $0.0166^{*}$ & $0.0998 \mathrm{~ns}$ & 12.5 \\
\hline & 5 th & $0.0031^{*}$ & $0.0179^{*}$ & $0.3943 \mathrm{~ns}$ & 17.3 \\
\hline \multirow{3}{*}{ Lycopene } & $1 \mathrm{st}$ & $0.0193^{*}$ & $<.0001^{*}$ & $0.0005^{*}$ & 14.8 \\
\hline & $3 \mathrm{rd}$ & $0.5929 \mathrm{~ns}$ & $<.0001^{*}$ & $0.7315 \mathrm{~ns}$ & 14.6 \\
\hline & 5 th & $0.9067 \mathrm{~ns}$ & $<.0001^{*}$ & $0.4442 \mathrm{~ns}$ & 8.2 \\
\hline \multirow{3}{*}{$\beta$-carotene } & $1 \mathrm{st}$ & $0.0006^{*}$ & $0.0002^{*}$ & $0.0360^{*}$ & 11.0 \\
\hline & $3 \mathrm{rd}$ & $0.0271^{*}$ & $<.0001^{*}$ & $<.0001^{*}$ & 7.2 \\
\hline & 5 th & $0.1317 \mathrm{~ns}$ & $<.0001^{*}$ & $<.0001^{*}$ & 6.9 \\
\hline
\end{tabular}

*: significant; ns: not significant $(\alpha=0.05)$ 
Juice

Between clusters, the effects of $\mathrm{N}$ were limited to fruits of the first bunch. Supplies of $\mathrm{N}$ from 10 to 16 $\mathrm{mol}_{\mathrm{c}} \mathrm{m}^{-3} \mathrm{NS}$ to the crop increased the juice percentage by $5 \%$, obtaining its lowest percentage $(82.2 \%)$ in the lowest $\mathrm{N}$ concentration in the nutrient solution (Figure $3 \mathrm{~A}$ ). With $\mathrm{K}$, the effects were observed in fruits of the last two clusters. When $\mathrm{K}$ went from 5 to $13 \mathrm{~mol}_{\mathrm{c}} \mathrm{m}^{-3} \mathrm{NS}$, the juice increased by 6 and $7 \%$, although its maximum values of 90 and $88 \%$ were obtained with $13 \mathrm{~mol}_{\mathrm{c}} \mathrm{m}^{-3} \mathrm{NS}$, in the third and fifth clusters, respectively (Figure 3B). These results agree with juice values of $90 \%$ in ball tomato produced in hydroponics (San MartínHernández et al., 2012). The best doses to increase this attribute were $16 \mathrm{~mol}_{\mathrm{c}} \mathrm{N} \mathrm{m}^{-3} \mathrm{NS}$ and from 9 to $13 \mathrm{~mol}_{\mathrm{c}}$ $\mathrm{K} \mathrm{m}^{-3} \mathrm{NS}$. In grapes, the juice content is an attribute that benefits from greater applications of $\mathrm{K}$ (Gawek et al., 2000), but its effects occur when enough $\mathrm{N}$ is applied at the same time (Ganeshamurthy et al., 2011). Sufficient $\mathrm{K}$ concentrations in plant tissues can facilitate an osmotic adjustment that maintains a high turgor pressure (Wang et al., 2013), which is associated with the water content in the cellular tissue and therefore the juice yield can increase as observed in this research.

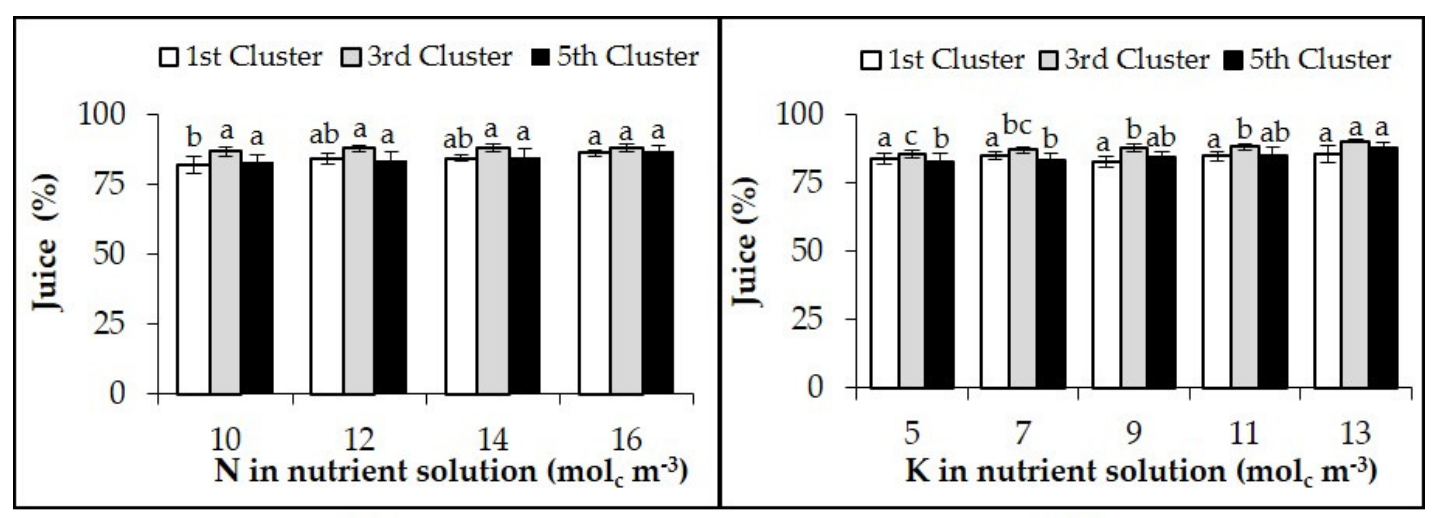

(A)

(B)

Figure 3. Percentage of fresh fruit juice in three tomato clusters according to the level of supply of $\mathrm{N}$ in the vegetative stage $(A)$ and of $K$ in the reproductive stage (B) of the crop

Means $\pm S D$ in each cluster and variable with different letters indicate statistical differences (Tukey, $p \leq 0.05$ )

\section{Total sugars}

An increase in $\mathrm{N}$ from 10 to $16 \mathrm{~mol}_{\mathrm{c}} \mathrm{m}^{-3} \mathrm{NS}$ increased the concentration of sugars by $12.5 \%$ in the fruits of the first cluster, achieving their highest concentration $\left(32.4 \mathrm{~g} \mathrm{~kg}^{-1} \mathrm{FF}\right.$ : fresh fruit) with $16 \mathrm{~mol}_{\mathrm{c}} \mathrm{N} \mathrm{m}^{-3} \mathrm{NS}$ (Figure 4A). Contrary to these results, high doses of $\mathrm{N}$ in tomato crops limit fruit sugar content (Parisi et al., 2006).

In carbohydrate metabolism, $\mathrm{K}$ plays important functions (Jensen et al., 2013), as a companion ion in the release of sugars from mesophyll cells of the leaves to the demand organs (Engels et al., 2012), affecting their distribution (Kanai et al., 2007). High sugar contents depend on the importation of sucrose to the fruit (Balibrea et al., 2006). In this experiment, when this cation changed from 5 to $13 \mathrm{~mol}_{\mathrm{c}} \mathrm{m}^{-3} \mathrm{NS}$, the concentration of sugars increased by 13,19 , and $20 \%$ in fruits of the first, third, and fifth clusters, respectively. Supplies between 9 and $13 \mathrm{~mol}_{\mathrm{c}} \mathrm{K} \mathrm{m}^{-3} \mathrm{NS}$ to the crop generated the highest values of sugars in the fruit (Figure 4B). Applications of $\mathrm{K}$ equivalent to 3.5 to $11.5 \mathrm{~mol}_{\mathrm{c}} \mathrm{m}^{-3} \mathrm{SN}$ in tomato increase the sugar content of the fruit by $26 \%$ (Caretto et al., 2008).

Between clusters, the concentration of sugars was differential and increased during the course of the crop. Roots, leaves, and fruits of clusters in formation and development compete for the supply of photosynthates. When the leaves senesce, the photosynthetic machinery is disorganized and the production of carbohydrates decreases (Falqueto et al., 2009). In tomato, pruning old leaves is part of the intensive 
management (Beyers et al., 2014), which could favor the increase of sugars in fruits of the third and fifth clusters (Figures $4 \mathrm{~A}$ and $4 \mathrm{~B})$.

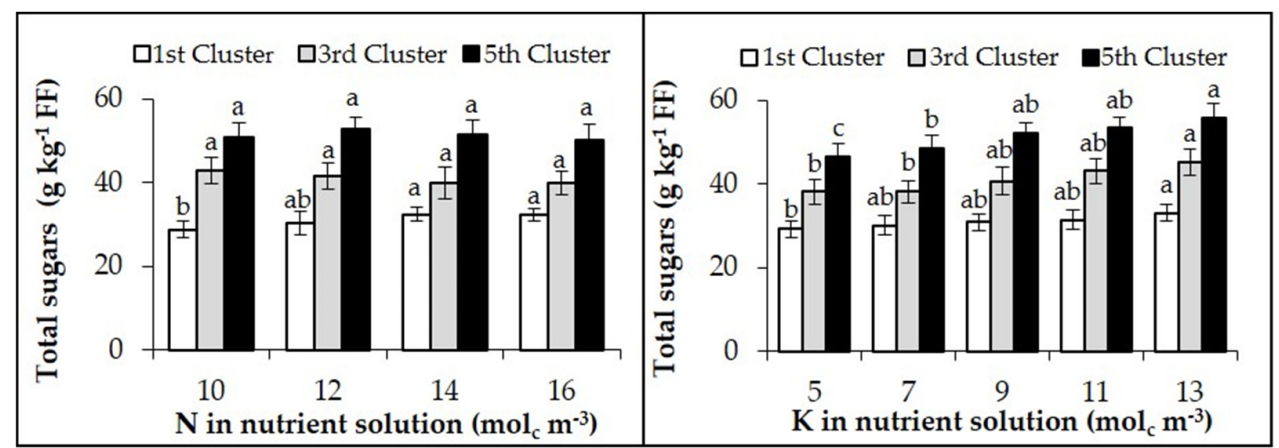

(A)

(B)

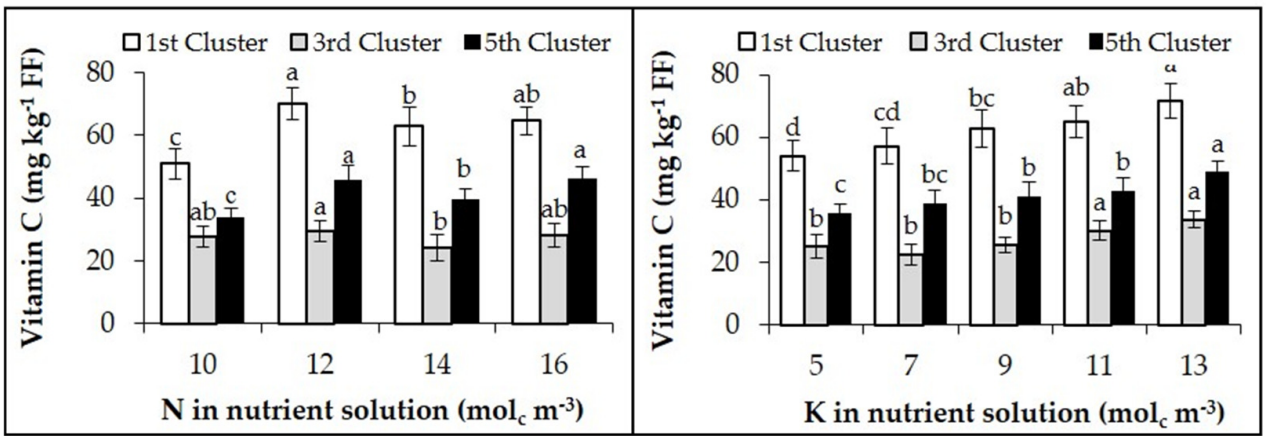

(C)

(D)

Figure 4. Concentration of total sugars $(A$ and $B)$ and vitamin $C(C$ and $D)$ in fresh fruit $(F F)$ of three tomato clusters according to the level of supply of $\mathrm{N}$ in the vegetative stage and of $\mathrm{K}$ in the reproductive stage of the crop

Means \pm SD in each cluster and variable with different letters indicate statistical differences (Tukey, $p \leq 0.05$ )

\section{Vitamin $C$}

Regardless of the $\mathrm{N}$ and $\mathrm{K}$ treatments evaluated, the vitamin $\mathrm{C}$ concentration of the fruit was higher in the first cluster and lower in the third (Figures $4 \mathrm{C}$ and 4D).

In tomato, high $\mathrm{N}$ applications during cultivation decrease the vitamin $\mathrm{C}$ content of the fruit (Dumas et al., 2003), while K exerts an opposite effect (Afzal et al., 2015).

Contrary to the literature, when the supply of $\mathrm{N}$ was increased in tomato cultivation (from 10 to 16 $\mathrm{mol}_{\mathrm{c}} \mathrm{m}^{-3} \mathrm{NS}$ ), the synthesis of vitamin $\mathrm{C}$ was favoured, although at $12 \mathrm{~mol}_{\mathrm{c}} \mathrm{N} \mathrm{m}^{-3} \mathrm{NS}$, the highest averages were obtained with 70, 30, and $46 \mathrm{mg} \mathrm{kg}^{-1} \mathrm{FF}$, in fruits of the first, third, and fifth clusters, respectively (Figure 4C).

On the other hand, by increasing the application of $\mathrm{K}$ from 5 to $13 \mathrm{~mol}_{\mathrm{c}} \mathrm{m}^{-3} \mathrm{NS}$, the concentration of vitamin $\mathrm{C}$ increased by 33, 38, and $37 \%$ in fruits of the first, third, and fifth clusters, respectively (Figure 4D). $\mathrm{L}$-ascorbic acid is a compound derived from carbohydrates, whose precursors are L-galactose, L-galactone-1,4lactone, and L-gulose (Lisko et al., 2014). The highest concentration of vitamin C obtained with the highest application of $\mathrm{K}$ to the crop can be associated with the transport and accumulation of sugars to the fruit (Bernardi and Verruma-Bernardi, 2013; Vicente et al., 2014), which favours its synthesis (Mengel and Kirkby, 2001). 


\section{Protein}

Despite the increase in fruit protein due to the supplied nitrogen levels, it decreased between clusters during cultivation. Applications of $\mathrm{N}$ from 10 to $16 \mathrm{~mol}_{\mathrm{c}} \mathrm{m}^{-3} \mathrm{NS}$ in the vegetative stage of the crop increased the protein content by 21,16 , and $7 \%$ in fruits of the first to fifth clusters (Figure $5 \mathrm{~A}$ ). The protein composition of the fruit results directly from the effects that nitrogen nutrition imposes on the crop (Rajasree and Pillai, 2012; Liu et al., 2016) since this nutrient facilitates the requirement for protein synthesis (Wang et al., 2014).

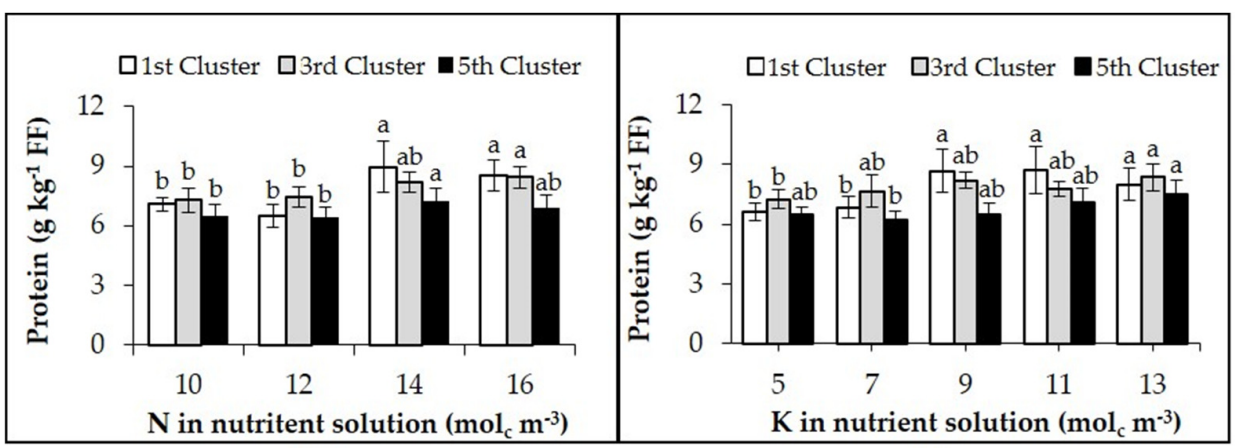

(A)

(B)

Figure 5. Concentration of protein in fresh fruit $(\mathrm{FF})$ of three tomato clusters according to the level of supply of $\mathrm{N}$ in the vegetative stage (A) and of $\mathrm{K}$ in the reproductive stage (B) of the crop

Means \pm SD in each cluster and variable with different letters indicate statistical differences (Tukey, $p \leq 0.05$ )

$\mathrm{K}$ supplies of 5 to $13 \mathrm{~mol}_{\mathrm{c}} \mathrm{m}^{-3} \mathrm{NS}$ in the reproductive stage of the crop increased the protein concentration of fruits of the first, third, and fifth clusters by 21,15 , and $16 \%$, respectively. However, with $\mathrm{K}$ between 9 and 13 mol $_{c} \mathrm{~m}^{-3} \mathrm{NS}$, the highest protein averages were obtained, being 8.7, 8.4, and $7.5 \mathrm{~g} \mathrm{~kg}^{-1} \mathrm{FF}$ in the first, third, and fifth clusters, respectively (Figure 5B). Protein synthesis is the most sensitive process due to the $\mathrm{K}$ level in the plant medium (Faust and Schubert, 2016).

In plant metabolism, $\mathrm{N}$ and $\mathrm{K}$ are closely related and both play a crucial role in protein synthesis (Coskun et al., 2017). The N:K combinations of 14:9 and 14:11 $\mathrm{mol}_{\mathrm{c}} \mathrm{m}^{-3} \mathrm{NS}$ were the ones that most increased the protein concentration in the first cluster with 10.5 and $12.2 \mathrm{~g} \mathrm{~kg}^{-1} \mathrm{FF}$, respectively (Table 2).

\section{Lycopene}

The increase in $\mathrm{N}$ from 10 to $16 \mathrm{~mol}_{\mathrm{c}} \mathrm{m}^{-3} \mathrm{NS}$ generated an inverse relationship with the concentration of lycopene in fruits harvested from the first cluster (Figure 6A). On this carotenoid, the literature is contradictory. The lycopene concentration in tomato increases from 38 to $68 \mathrm{mg} \mathrm{kg}^{-1} \mathrm{FF}$ when the $\mathrm{N}$ supplied to the crop decreases from 15.8 to $1 \mathrm{~mol}_{\mathrm{c}} \mathrm{m}^{-3} \mathrm{SN}$ (Dumas et al., 2003). Similar responses were found in another research report (Wang et al., 2015). In contrast, small increases in $\mathrm{N}$ fertilization during cultivation increase the lycopene content of the fruit (Kuscu et al., 2014; Hui et al., 2017). Indeed, N and K status in the culture media may significantly affect various quality attributes of tomato fruits. Thus, when providing $\mathrm{N}$ or $\mathrm{K}$ at suboptimal levels, the gradual increase of such nutrients positively affects quality traits such as lycopene content. Conversely, when such nutrients are supplied at sufficient or high levels, quality attributes are negatively affected (Souri et al., 2018; Souri and Hatamian, 2019).

On the other hand, when $\mathrm{K}$ increased from 5 to $13 \mathrm{~mol}_{\mathrm{c}} \mathrm{m}^{-3} \mathrm{NS}$ in the reproductive stage of the crop, the lycopene concentration increased by 39,49 , and $51 \%$ in fruits of the first, third, and fifth clusters, respectively (Figure 6B). The increase in the lycopene concentration has been related to the increase in the supply of $\mathrm{K}$ to the tomato crop (Taber et al., 2008). Regarding carbohydrate metabolism, K modulates the enzymes pyruvate kinase and phosphofructokinase, and the formation of acetyl CoA is affected, which is involved in obtaining isopentenyl diphosphate, the first precursor of carotenoids (Fanasca et al., 2006; Vasák and Schabl, 2016). 
Table 2. Effect of the combinations of $\mathrm{N}$ in the vegetative stage and of $\mathrm{K}$ in the reproductive stage (N:K), during tomato cultivation, on the concentration of protein in fruits of the first, third, and fifth clusters

\begin{tabular}{|l|c|c|c|}
\hline \multirow{2}{*}{$\begin{array}{c}\mathrm{N}: \mathrm{K} \\
\left(\mathrm{mol}_{\mathrm{c}} \mathrm{m}^{-3}\right)\end{array}$} & \multicolumn{3}{|c|}{ Protein $\left(\mathrm{g} \mathrm{kg}^{-1}\right.$ fresh fruit $)$} \\
\cline { 2 - 4 } $10: 5$ & $7.2 \pm 0.2 \mathrm{cdefg}$ & $3 \mathrm{rd}$ & 5 th \\
\hline $10: 7$ & $7.2 \pm 0.2 \mathrm{cdefg}$ & $6.9 \pm 0.5 \mathrm{a}$ & $6.4 \pm 0.2 \mathrm{a}$ \\
\hline $10: 9$ & $7.3 \pm 0.6 \mathrm{cdefg}$ & $6.6 \pm 1.0 \mathrm{a}$ & $6.0 \pm 0.8 \mathrm{a}$ \\
\hline $10: 11$ & $6.8 \pm 0.5 \mathrm{defg}$ & $8.3 \pm 0.3 \mathrm{a}$ & $7.8 \pm 0.5 \mathrm{a}$ \\
\hline $10: 13$ & $6.8 \pm 0.2 \mathrm{defg}$ & $7.1 \pm 0.3 \mathrm{a}$ & $6.9 \pm 0.2 \mathrm{a}$ \\
\hline $12: 5$ & $6.1 \pm 0.4 \mathrm{fg}$ & $7.7 \pm 0.6 \mathrm{a}$ & $6.1 \pm 0.4 \mathrm{a}$ \\
\hline $12: 7$ & $5.8 \pm 0.6 \mathrm{~g}$ & $7.0 \pm 0.3 \mathrm{a}$ & $6.2 \pm 0.6 \mathrm{a}$ \\
\hline $12: 9$ & $6.9 \pm 0.8 \mathrm{defg}$ & $6.7 \pm 0.6 \mathrm{a}$ & $7.1 \pm 0.7 \mathrm{a}$ \\
\hline $12: 11$ & $7.0 \pm 0.3 \mathrm{defg}$ & $7.5 \pm 0.3 \mathrm{a}$ & $6.2 \pm 0.3 \mathrm{a}$ \\
\hline $12: 13$ & $6.8 \pm 0.6 \mathrm{defg}$ & $8.4 \pm 0.4 \mathrm{a}$ & $6.5 \pm 0.1 \mathrm{a}$ \\
\hline $14: 5$ & $6.2 \pm 0.1 \mathrm{fg}$ & $7.6 \pm 0.6 \mathrm{a}$ & $6.9 \pm 0.2 \mathrm{a}$ \\
\hline $14: 7$ & $6.5 \pm 0.5 \mathrm{efg}$ & $7.3 \pm 0.6 \mathrm{a}$ & $6.6 \pm 0.2 \mathrm{a}$ \\
\hline $14: 9$ & $10.5 \pm 1.1 \mathrm{ab}$ & $8.3 \pm 0.5 \mathrm{a}$ & $6.7 \pm 0.2 \mathrm{a}$ \\
\hline $14: 11$ & $12.2 \pm 0.1 \mathrm{a}$ & $9.4 \pm 0.0 \mathrm{a}$ & $7.7 \pm 0.7 \mathrm{a}$ \\
\hline $14: 13$ & $9.4 \pm 0.3 \mathrm{bcd}$ & $7.7 \pm 0.2 \mathrm{a}$ & $8.4 \pm 1.0 \mathrm{a}$ \\
\hline $16: 5$ & $7.0 \pm 0.6 \mathrm{defg}$ & $8.6 \pm 0.5 \mathrm{a}$ & $6.6 \pm 0.6 \mathrm{a}$ \\
\hline $16: 7$ & $7.8 \pm 0.1 \mathrm{bcdefg}$ & $7.9 \pm 0.5 \mathrm{a}$ & $6.7 \pm 0.1 \mathrm{a}$ \\
\hline $16: 9$ & $10.0 \pm 0.3 \mathrm{abc}$ & $9.0 \pm 0.5 \mathrm{a}$ & $6.2 \pm 0.2 \mathrm{a}$ \\
\hline $16: 11$ & $8.8 \pm 0.7 \mathrm{bcdef}$ & $7.9 \pm 0.3 \mathrm{a}$ & $6.8 \pm 0.9 \mathrm{a}$ \\
\hline $16: 13$ & $9.1 \pm 1.0 \mathrm{bcde}$ & $7.9 \pm 0.2 \mathrm{a}$ & $8.3 \pm 0.9 \mathrm{a}$ \\
\hline
\end{tabular}

Means \pm SD in each column with different letters indicate statistical differences (Tukey, $\mathrm{p} \leq 0.05$ )

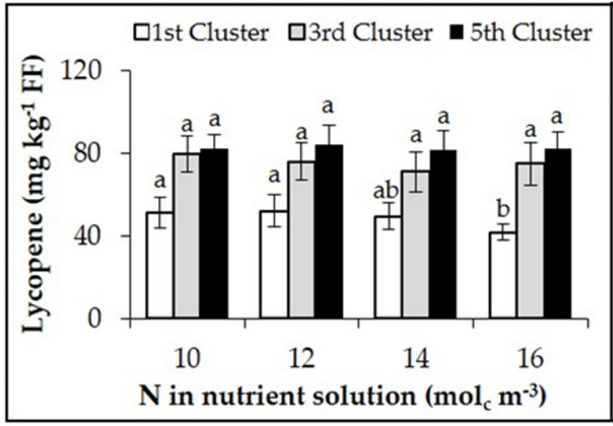

(A)

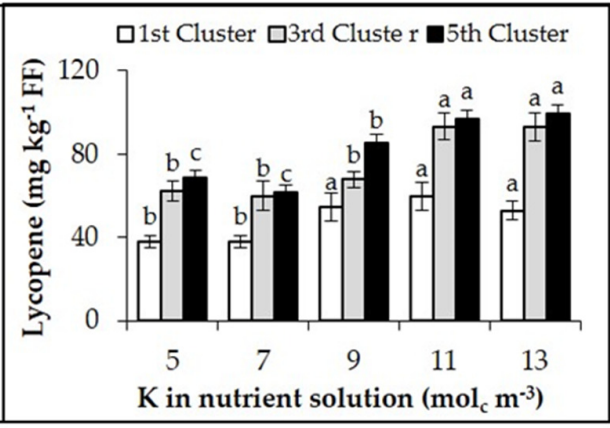

(B)

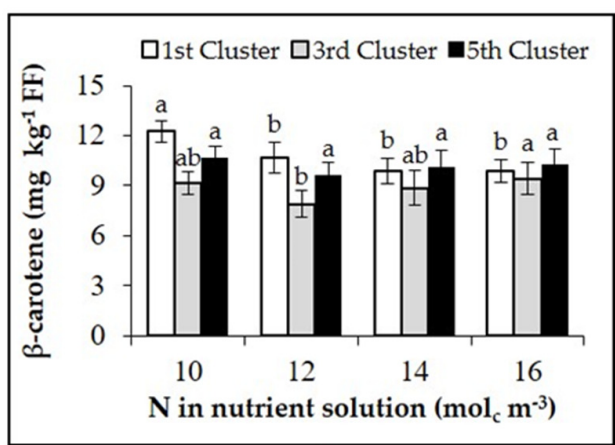

(C)

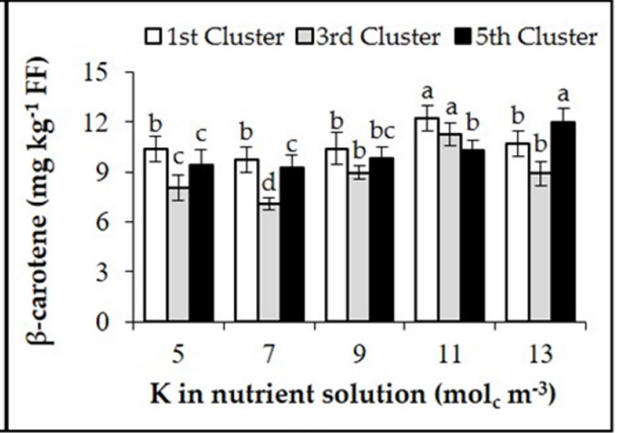

(D)

Figure 6. Concentration of lycopene $(A$ and $B)$ and $\beta$-carotene $(C$ and $D)$ in fresh fruit $(F F)$ of three tomato clusters according to the level of supply of $\mathrm{N}$ in the vegetative stage and of $\mathrm{K}$ in the reproductive stage of the crop

Means \pm SD in each cluster and variable with different letters indicate statistical differences (Tukey, $p \leq 0.05$ ) 
The highest lycopene concentrations were recorded with $\mathrm{K}$ from 9 to $13 \mathrm{~mol}_{\mathrm{c}} \mathrm{m}^{-3} \mathrm{NS}$ (Figure 6B) and with $\mathrm{N}$ doses of less than or equal to $14 \mathrm{~mol}_{\mathrm{c}} \mathrm{m}^{-3} \mathrm{NS}$ (Figure $6 \mathrm{~A}$ ); thus, the best $\mathrm{N}: \mathrm{K}$ combinations to promote lycopene synthesis were 10:9, 12:11, 14:11, and 10:13 $\mathrm{mol}_{\mathrm{c}} \mathrm{m}^{-3} \mathrm{NS}$ (Table 3).

Lycopene synthesis increased in fruits from the first to the fifth cluster. From November to December, temperatures lower than $30^{\circ} \mathrm{C}$ were recorded (Figure 5); this coincided with the harvest of the last two clusters. High temperatures inhibit lycopene synthesis, being optimal between 18 and $26{ }^{\circ} \mathrm{C}$; therefore, if the temperature exceeds $30^{\circ} \mathrm{C}$, the lycopene content decreases (Brandt et al., 2006).

Table 3. Effect of the combinations of $\mathrm{N}$ in the vegetative stage and of $\mathrm{K}$ in the reproductive stage ( $\mathrm{N}: \mathrm{K})$, during tomato cultivation, on the concentration of lycopene and $\beta$-carotene in fruits of the first, third, and fifth clusters

\begin{tabular}{|l|c|c|c|c|c|c|}
\hline \multirow{2}{*}{$\begin{array}{c}\text { N:K } \\
\left(\mathrm{mol}_{\mathrm{c}} \mathrm{m}^{-3}\right)\end{array}$} & \multicolumn{2}{|c|}{ Lycopene $\left(\mathrm{mg} \mathrm{kg}^{-1}\right.$ fresh fruit $)$} & \multicolumn{2}{c|}{$\beta$-carotene $\left(\mathrm{mg} \mathrm{kg}^{-1}\right.$ fresh fruit $)$} \\
\cline { 2 - 7 } & $1 \mathrm{st}$ & $3 \mathrm{rd}$ & $5 \mathrm{th}$ & $1 \mathrm{st}$ & $3 \mathrm{rd}$ & 5 th \\
\hline $10: 5$ & $38.8 \pm 0.8 \mathrm{cde}$ & $68.0 \pm 6.2 \mathrm{a}$ & $68.6 \pm 5.2 \mathrm{a}$ & $12.1 \pm 0.5 \mathrm{abcd}$ & $8.4 \pm 0.1 \mathrm{defgh}$ & $11.2 \pm 0.6 \mathrm{bc}$ \\
\hline $10: 7$ & $37.5 \pm 1.2 \mathrm{cde}$ & $71.3 \pm 0.9 \mathrm{a}$ & $68.2 \pm 2.3 \mathrm{a}$ & $11.7 \pm 0.4 \mathrm{abcde}$ & $7.7 \pm 0.1 \mathrm{efgh}$ & $10.8 \pm 0.3 \mathrm{bcd}$ \\
\hline $10: 9$ & $73.2 \pm 1.1 \mathrm{a}$ & $66.6 \pm 4.2 \mathrm{a}$ & $80.1 \pm 5.0 \mathrm{a}$ & $13.5 \pm 0.1 \mathrm{a}$ & $9.0 \pm 0.2 \mathrm{cdefg}$ & $8.2 \pm 0.6 \mathrm{ef}$ \\
\hline $10: 11$ & $51.4 \pm 6.1 \mathrm{abcde}$ & $95.4 \pm 1.4 \mathrm{a}$ & $92.5 \pm 0.8 \mathrm{a}$ & $12.7 \pm 1.1 \mathrm{abc}$ & $11.3 \pm 0.3 \mathrm{abc}$ & $9.4 \pm 0.1 \mathrm{cdef}$ \\
\hline $10: 13$ & $55.2 \pm 5.3 \mathrm{abcde}$ & $96.2 \pm 12.0 \mathrm{a}$ & $100.6 \pm 0.9 \mathrm{a}$ & $11.2 \pm 0.4 \mathrm{abcde}$ & $9.3 \pm 0.7 \mathrm{bcdef}$ & $13.8 \pm 0.3 \mathrm{a}$ \\
\hline $12: 5$ & $39.1 \pm 4.9 \mathrm{cde}$ & $62.5 \pm 5.8 \mathrm{a}$ & $71.4 \pm 3.0 \mathrm{a}$ & $9.3 \pm 0.7 \mathrm{bcde}$ & $6.7 \pm 0.4 \mathrm{gh}$ & $8.2 \pm 0.4 \mathrm{ef}$ \\
\hline $12: 7$ & $33.8 \pm 2.1 \mathrm{de}$ & $58.4 \pm 9.0 \mathrm{a}$ & $59.3 \pm 2.5 \mathrm{a}$ & $9.9 \pm 0.8 \mathrm{abcde}$ & $6.1 \pm 0.1 \mathrm{~h}$ & $7.6 \pm 0.4 \mathrm{f}$ \\
\hline $12: 9$ & $59.2 \pm 1.8 \mathrm{abc}$ & $75.3 \pm 0.5 \mathrm{a}$ & $92.0 \pm 5.2 \mathrm{a}$ & $9.4 \pm 0.4 \mathrm{bcde}$ & $9.7 \pm 0.1 \mathrm{bcde}$ & $10.4 \pm 0.3 \mathrm{bcde}$ \\
\hline $12: 11$ & $72.2 \pm 1.6 \mathrm{a}$ & $99.3 \pm 3.3 \mathrm{a}$ & $98.5 \pm 6.9 \mathrm{a}$ & $12.9 \pm 0.4 \mathrm{ab}$ & $9.8 \pm 0.4 \mathrm{bcde}$ & $9.4 \pm 0.3 \mathrm{cdef}$ \\
\hline $12: 13$ & $56.3 \pm 5.7 \mathrm{abcd}$ & $84.1 \pm 4.8 \mathrm{a}$ & $100.3 \pm 6.2 \mathrm{a}$ & $12.0 \pm 0.9 \mathrm{abcde}$ & $7.2 \pm 0.1 \mathrm{fgh}$ & $12.4 \pm 0.0 \mathrm{ab}$ \\
\hline $14: 5$ & $41.4 \pm 1.7 \mathrm{cde}$ & $57.7 \pm 6.1 \mathrm{a}$ & $64.0 \pm 2.4 \mathrm{a}$ & $10.8 \pm 0.5 \mathrm{abcde}$ & $6.8 \pm 0.1 \mathrm{gh}$ & $7.1 \pm 0.3 \mathrm{f}$ \\
\hline $14: 7$ & $43.7 \pm 4.6 \mathrm{cde}$ & $53.3 \pm 5.8 \mathrm{a}$ & $57.5 \pm 3.3 \mathrm{a}$ & $8.4 \pm 0.6 \mathrm{e}$ & $7.7 \pm 0.2 \mathrm{efgh}$ & $10.2 \pm 0.4 \mathrm{bcde}$ \\
\hline $14: 9$ & $42.3 \pm 3.4 \mathrm{cde}$ & $64.3 \pm 1.2 \mathrm{a}$ & $86.8 \pm 2.9 \mathrm{a}$ & $9.5 \pm 0.3 \mathrm{bcde}$ & $8.7 \pm 0.2 \mathrm{defg}$ & $11.2 \pm 0.5 \mathrm{bc}$ \\
\hline $14: 11$ & $68.2 \pm 4.1 \mathrm{ab}$ & $87.4 \pm 11.2 \mathrm{a}$ & $100.2 \pm 5.6 \mathrm{a}$ & $11.7 \pm 0.7 \mathrm{abcde}$ & $12.3 \pm 0.9 \mathrm{a}$ & $10.2 \pm 0.1 \mathrm{bcde}$ \\
\hline $14: 13$ & $51.9 \pm 6.4 \mathrm{abcde}$ & $92.2 \pm 4.0 \mathrm{a}$ & $98.5 \pm 4.0 \mathrm{a}$ & $9.1 \pm 0.6 \mathrm{cde}$ & $8.9 \pm 0.3 \mathrm{cdefg}$ & $11.8 \pm 0.7 \mathrm{abc}$ \\
\hline $16: 5$ & $32.7 \pm 1.6 \mathrm{e}$ & $61.3 \pm 3.3 \mathrm{a}$ & $71.3 \pm 2.1 \mathrm{a}$ & $9.4 \pm 0.4 \mathrm{bcde}$ & $10.2 \pm 0.2 \mathrm{abcd}$ & $11.1 \pm 0.2 \mathrm{bc}$ \\
\hline $16: 7$ & $36.7 \pm 1.7 \mathrm{cde}$ & $57.0 \pm 8.9 \mathrm{a}$ & $61.3 \pm 3.8 \mathrm{a}$ & $8.9 \pm 0.2 \mathrm{de}$ & $6.7 \pm 0.1 \mathrm{gh}$ & $8.3 \pm 0.4 \mathrm{def}$ \\
\hline $16: 9$ & $44.1 \pm 2.8 \mathrm{cde}$ & $65.5 \pm 6.1 \mathrm{a}$ & $83.7 \pm 2.6 \mathrm{a}$ & $9.2 \pm 0.2 \mathrm{cde}$ & $8.4 \pm 0.7 \mathrm{defgh}$ & $9.5 \pm 0.1 \mathrm{cdef}$ \\
\hline $16: 11$ & $47.7 \pm 4.1 \mathrm{bcde}$ & $90.6 \pm 7.3 \mathrm{a}$ & $96.3 \pm 3.8 \mathrm{a}$ & $11.7 \pm 1.0 \mathrm{abcde}$ & $11.6 \pm 0.5 \mathrm{ab}$ & $12.3 \pm 0.2 \mathrm{ab}$ \\
\hline $16: 13$ & $48.2 \pm 1.5 \mathrm{bcde}$ & $99.6 \pm 3.9 \mathrm{a}$ & $98.8 \pm 5.3 \mathrm{a}$ & $10.4 \pm 0.3 \mathrm{abcde}$ & $10.2 \pm 0.5 \mathrm{abcd}$ & $10.1 \pm 0.6 \mathrm{bcde}$ \\
\hline
\end{tabular}

Means \pm SD in each column with different letters indicate statistical differences (Tukey, $\mathrm{p} \leq 0.05$ )

\section{$\beta$-carotene}

Although the increase in $\mathrm{N}$ from 10 to $16 \mathrm{~mol}_{\mathrm{c}} \mathrm{m}^{-3} \mathrm{NS}$ decreased the $\beta$-carotene concentration in fruits of the first cluster by $20 \%$, in the third it increased by $19 \%$ between 12 and $16 \mathrm{~mol}_{\mathrm{c}} \mathrm{m}^{-3} \mathrm{NS}$ (Figure 6C). In contrast, a supply of $\mathrm{K}$ from 5 to $13 \mathrm{~mol}_{\mathrm{c}} \mathrm{m}^{-3} \mathrm{NS}$ improved the synthesis of $\beta$-carotene by 3,11 , and $28 \%$, in fruits of the first, third, and fifth clusters, respectively (Figure 6D). Similar responses have been obtained when $\mathrm{K}$ is raised from 8 to $9 \mathrm{~mol}_{\mathrm{c}} \mathrm{m}^{-3} \mathrm{NS}$ in tomato (Ramírez et al., 2012). In strawberries and pepper, increasing the $\mathrm{K}$ supply from $210 \mathrm{mg} \mathrm{L}^{-1}$ to $350 \mathrm{mg} \mathrm{L}^{-1}$ in the nutrient solution significantly increased key quality attributes of fruits (Tohidloo et al., 2018).

In general, increases in $\mathrm{K}$ at each level of $\mathrm{N}$ stimulated the synthesis of $\beta$-carotene, achieving its maximum values with $\mathrm{K}$ between 9 and $13 \mathrm{~mol}_{\mathrm{c}} \mathrm{m}^{-3} \mathrm{NS}$, while $\mathrm{N}$ concentrations less than or equal to $14 \mathrm{~mol}_{\mathrm{c}}$ $\mathrm{m}^{-3} \mathrm{NS}$ favoured the best level of this pigment. Therefore, the $\mathrm{N}: \mathrm{K}$ combinations that most promoted the synthesis of $\beta$-carotene were 10:9, 10:13, and 14:11 (Table 3).

The concentration of $\beta$-carotene varied between clusters, being higher in the first than in the fifth and third (Figures 6C and 6D). High temperatures can promote the conversion of lycopene to $\beta$-carotene (Dorais 
et al., 2008). In this study, the harvest of the first cluster coincided with the highest recorded temperatures (Figure 1).

\section{Conclusions}

Herewith we demonstrated that the concentration of carotenoids and the nutritional value of tomato fruits were influenced by $\mathrm{N}$ and $\mathrm{K}$ supply at different phenological stages. Nonetheless, these effects changed slightly according to the origin of the fruit among the three clusters analysed.

Increasing $\mathrm{N}$ supply in the vegetative stage of the crop increased the concentrations of protein, vitamin $\mathrm{C}$, sugars (temporarily) and fruit juice. However, at the beginning of production, carotenoid synthesis may have been decreased due to the effects of $\mathrm{N}$. Applications of $\mathrm{N}$ from 12 to $16 \mathrm{~mol}_{\mathrm{c}} \mathrm{m}^{-3} \mathrm{NS}$ until the anthesis of the first cluster of the crop promoted the highest concentrations of protein and vitamin $\mathrm{C}$ of the fruit. Likewise, supplying $\mathrm{K}$ from 11 to $13 \mathrm{~mol}_{\mathrm{c}} \mathrm{m}^{-3} \mathrm{NS}$ during the reproductive stage of the crop resulted in the highest concentrations of sugars, vitamin $\mathrm{C}$, juice, protein, lycopene and $\beta$-carotene. The $\mathrm{N} x \mathrm{~K}$ interaction improved the synthesis of protein, lycopene and $\beta$-carotene. In order to get the highest concentrations of such molecules (i.e. protein, lycopene and $\beta$-carotene), the combinations $\mathrm{N}: \mathrm{K} 14: 11,10: 9$ and 10:13 $\mathrm{mol}_{\mathrm{c}} \mathrm{m}^{-3} \mathrm{NS}$, respectively, are suggested. Additionally, among the flower clusters from the first to the fifth, the nutritional constitution of the fruit shows different trends such as increases in sugars and lycopene, reductions in protein and a differential behavior in juice, vitamin $C$ and $\beta$-carotene.

\section{Authors' Contributions}

Conceptualization: LITT, FCGM; Methodology: LITT, CSMH; Validation: LITT; Formal analysis: CSMH, EAQO, MDMR; Investigation; CSMH, FCGM; Resources; LITT, CSV; Writing-original draft: CSMH, FCGM; Writing-review and editing: LITT, EAQO, MDMR, CSV; Supervision: LITT, FCGM; Project administration: LITT. All authors read and approved the final manuscript.

\section{Acknowledgements}

This research received no specific grant from any funding agency in the public, commercial, or not-forprofit sectors.

\section{Conflict of Interests}

The authors declare that there are no conflicts of interest related to this article.

\section{References}

Afzal I, Hussain B, Ahmed-Basra SM, Ullah SH, Shakeel Q, Kamran M (2015). Foliar application of potassium improves fruit quality and yield of tomato plants. Acta Scientiarum Polonorum Hortorum Cultus 14(1):3-13.

Ahmad N, Sarfraz M, Farooq U, Arfan-ul-Haq M, Zaighum-Mushtaq M, Azhar-Ali M (2015). Effect of potassium and its time of application on yield and quality of tomato. International Journal of Scientific and Research Publications 5(9):1-4. 
San Martín-Hernández C, Gómez-Merino FC et al. (2021). Not Bot Horti Agrobo 49(2):12320

Almeselmani M, Pant RC, Singh B (2009). Potassium level and physiological response and fruit quality in hydroponically grown tomato. International Journal of Vegetable Science 16(1):85-99. https://doi.org/10.1080/19315260903271526

AOAC (2002). Official Methods of Analysis of AOAC International. Association of Official Analytical Chemists (17th ed), Washington DC.

Arah IK, Amaglo H, Kumah EK, Ofori H (2015). Preharvest and postharvest factors affecting the quality and shelf life of harvested tomatoes: a mini review. International Journal of Agronomy 2015:478041. https://doi.org/10.1155/2015/478041

Balibrea ME, Martínez-Andújar C, Cuartero J, Bolarín MC, Pérez-Alfocea F (2006). The high fruit soluble sugar content in wild Lycopersicon species and their hybrids with cultivars depends on sucrose import during ripening rather than on sucrose metabolism. Functional Plant Biology 33(3):279-288. https://doi.org/10.1071/FP05134

Beckles DM (2012). Factors affecting the postharvest soluble solids and sugar content of tomato (Solanum lycopersicum L.) fruit. Postharvest Biology and Technology 63(1):129-140. https://doi.org/10.1016/j.postharvbio.2011.05.016

Bernardi ACC, Verruma-Bernardi MR (2013). Increases in yield and vitamin C levels of tomato grown on $\mathrm{K}_{2} \mathrm{HPO}_{4^{-}}$ enriched zeolite in an inert-sand substrate. e-ifc 33:10-13.

Beyers T, Vos C, Aerts R, Heyens K, Vogels L, Seels B, Höfte M, Cammue BPA, De Coninck B (2014). Resistance against Botrytis cinerea in smooth leaf pruning wounds of tomato does not depend on major disease signalling pathways. Plant Pathology 63(1):165-173. https://doi.org/10.1111/ppa.12075

Bhowmik D, Kumar KPS, Paswan S, Srivastava S (2012). Tomato-a natural medicine and its health benefits. Journal of Pharmacognosy and Phytochemistry 1(1):33-43.

Brandt S, Pek Z, Barna E, Lugasi A, Helyes L (2006). Lycopene content and color ripening tomatoes as affected by environmental conditions. Journal of the Science of Food and Agriculture 86(4):568-572. https://doi.org/10.1002/jsfa.2390

Burton-Freeman B, Reimers K (2011). Tomato consumption and health: emerging benefits. American Journal of Lifestyle Medicine 5(2):182-191. https://doi.org/10.1177/1559827610387488

Caretto S, Parente A, Serio F, Santamaria P (2008). Influence of potassium and genotype on vitamin E content and reducing sugar of tomato fruits. HortScience 43(7):2048-2051. https://doi.org/10.21273/HORTSCI.43.7.2048

Cebolla-Cornejo J, Roselló S, Valcárcel M, Serrano E, Beltrán J, Nuez F (2011). Evaluation of genotype and environment effects on taste and aroma flavor components of Spanish fresh tomato varieties. Journal of Agricultural and Food Chemistry 59(6):2440-2450. https://doi.org/10.1021/jf1045427

Coskun D, Britto DT, Kronzucker HJ (2017). The nitrogen-potassium intersection: membranes, metabolism, and mechanism. Plant Cell and Environment 40(10):2029-2041. https://doi.org/10.1111/pce.12671

Coyago-Cruz E, Corell M, Moriana A, Hernanz D, Benítez-González AM, Stinco CM, Meléndez-Martínez AJ (2018). Antioxidants (carotenoids and phenolics) profile of cherry tomatoes as influenced by deficit irrigation, ripening and cluster. Food Chemistry 240(1):870-884. https://doi.org/10.1016/j.foodchem.2017.08.028

Dehnavard S, Souri MK, Mardanlu S (2017). Tomato growth responses to foliar application of ammonium sulfate in hydroponic culture. Journal of Plant Nutrition 40(3):315-323. https://doi.org/10.1080/01904167.2016.1240191

Dorais M, Ehret DL, Papadopoulos AP (2008). Tomato (Solanum lycopersicum) health components: from the seed to the consumer. Phytochemistry Reviews 7:231-250. https://doi.org/10.1007/s11101-007-9085-X

Dumas Y, Dadomo M, Lucca GD, Grolier P (2003). Effects of environmental factors and agricultural techniques on antioxidant content of tomatoes. Journal of the Science of Food and Agriculture 83(5):369-382. https://doi.org/10.1002/jsfa.1370

Ehsan-Akhtar M, Zammer-Khan M, Tahir-Rashid M, Ahsan Z, Ahmad S (2010). Effect of potash application on yield and quality of tomato (Lycopersicon esculentum Mill.). Pakistan Journal of Botany 42(3):1695-1702.

Engels C, Kirkby E, White P (2012). Mineral nutrition, yield and source-sink relationships. In: Marschner P (Ed). Marschner's Mineral Nutrition of Higher Plants. Academic Press, Elsevier Inc. San Diego, CA, USA pp 85-133. https://doi.org/10.1016/B978-0-12-384905-2.00005-4

Falqueto AR, Cassol D, Magalhaes-Júnior AM, Oliveira AC, Bacarin MA (2009). Physiological analysis of leaf senescence of two rice cultivars with different yield potential. Pesquisa Agropecuária Brasileira 44(7):695-700. https://doi.org/10.1590/S0100-204X2009000700007 
Fanasca S, Colla G, Maiani G, Venneria E, Rouphael Y, Azzini E, Saccardo F (2006). Changes in antioxidant content of tomato fruits in response to cultivar and nutrient solution composition. Journal of Agricultural and Food Chemistry 54(12):4319-4325. https://doi.org/10.1021/jf0602572

FAO (2018). Food supply quantity (kg/capita/yr), tomatoes and products. Retrieved 2018 January 10 from http://www.fao.org/faostat/en/\#compare

Faust F, Schubert S (2016). Protein synthesis is the most sensitive process when potassium is substituted by sodium nutrition of sugar beet (Beta vulgaris). Plant Physiology and Biochemistry 107:237-247. https://doi.org/10.1016/j.plaphy.2016.06.009

Fujihara S, Kasuga A, Aoyagi Y (2001). Nitrogen-to-protein conversion factors for common vegetables in Japan. Journal of Food Science 66(3):412-415. https://doi.org/10.1111/j.1365-2621.2001.tb16119.x

Ganeshamurthy AN, Satisha GC, Patil P (2011). Potassium nutrition on yield and quality of crops with special emphasis on banana and grapes. Karnataka Journal of Agricultural Science 24(1):29-38.

Gawel RR, Ewart AJW, Cirami R (2000). Effect of rootstock on must and wine composition and the sensory properties of Cabernet Sauvignon grown at Langhorne Creek, South Australia. Australian and New Zealand Wine Industry Journal 15:67-73.

Hawkesford M, Horst W, Kichey T, Lambers H, Schjoerring J, Moller IS, White P (2012). Functions of macronutrients. In: Marschner P (Ed). Marschner's Mineral Nutrition of Higher Plants. Academic Press, Elsevier Inc. San Diego, CA, USA pp 135-189. https://doi.org/10.1016/B978-0-12-384905-2.00006-6

Hui Y, Hongxia C, Xinmei H, Lijie G, Hongzheng L, Xuanyi W (2017). Evaluation of tomato fruit quality response to water and nitrogen management under alternate partial root-zone irrigation. International Journal of Agricultural and Biological Engineering 10(5):85-94. https://ijabe.org/index.php/ijabe/article/view/2622

Jensen KH, Savage JA, Holbrook NM (2013). Optimal concentration for sugar transport in plants. Journal of the Royal Society Interface 20130055. https://doi.org/10.1098/rsif.2013.0055

Jones B, Nachtsheim CJ (2009). Split-plot designs: what, why, and how. Journal of Quality Technology 41(4):340-361. https://doi.org/10.1080/00224065.2009.11917790

Jones JBJ (2008). Tomato plant culture in the field, greenhouse and home garden. CRC Press, Taylor and Francis Group (2nd ed), Boca Raton, FL.

Kanai S, Okhura K, Adu-Gyamfi JJ, Mohapatra PK, Nguyen NT, Saneoka H, Fujita K (2007). Depression of sink activity precedes the inhibition of biomass production in tomato plants subjected to potassium deficiency stress. Journal of Experimental Botany 58(11):2917-2928. https://doi.org/10.1093/jxb/erm 149

Kuehl OR (2000). Design of experiments: statistical principles of research design and analysis. Duxbury Press (2nd ed), Pacific Grove, CA.

Kuscu H, Turhan A, Ozmen N, Aydinol P, Demir AO (2014). Optimizing levels of water and nitrogen applied through drip irrigation for yield, and water productivity of processing tomato (Lycopersicon esculentum Mill.). Horticulture, Environment and Biotechnology 55:103-114. https://doi.org/10.1007/s13580-014-0180-9

Leghary SJ, Wahocho AN, Laghari GM, HafeezLaghari A, MustafaBhabhan G, Hussain Talpur K, Bhutto TA, Wahocho SA, Lashari AA (2016). Role of nitrogen for plant growth and development: A review. Advances in Environmental Biology 10(9):209-218.

Lin $\mathrm{CH}$, Chen BH (2003). Determination of carotenoids in tomato juice by liquid chromatography. Journal of Chromatography A 1012(1):103-109. https://doi.org/10.1016/S0021-9673(03)01138-5

Lisko KA, Aboobucker SI, Torres R, Lorence A (2014). Engineering elevated vitamin C in plants to improve their nutritional content, growth, and tolerance to abiotic stress. In: Jetter R (Ed). Phytochemicals-Biosynthesis, Function and Application. Springer, International Publishing Switzerland, Switzerland, pp 109-128. https://doi.org/10.1007/978-3-319-04045-5

Liu J, Wu N, Wang H, Sun J, Peng B, Jiang P, Bai E (2016). Nitrogen addition affects chemical compositions of plant tissues, litter and soil organic matter. Ecology 97(7):1796-1806. https://doi.org/10.1890/15-1683.1

Mardanluo S, Souri MK, Ahmadi M (2018). Plant growth and fruit quality of two pepper cultivars under different potassium levels of nutrient solutions. Journal of Plant Nutrition 41(12):1604-1614. https://doi.org/10.1080/01904167.2018.1463383

Mengel K, Kirkby EA (2001). Principles of plant nutrition. Kluwer Academic Publishers (5th ed), Dordrecht, The Netherlands.

NNDSR (2018). Tomatoes, red, ripe, raw, year-round average. Basic Report 11529. USDA. Retrieved 2018 September 18 from https://ndb.nal.usda.gov/ndb/ 
San Martín-Hernández C, Gómez-Merino FC et al. (2021). Not Bot Horti Agrobo 49(2):12320

Oosterhuis DM, Loka DA, Kawakami EM, Pettigrew WT (2014). The physiology of potassium in crop production. Advances in Agronomy 126:203-233. https://doi.org/10.1016/B978-0-12-800132-5.00003-1

Parisi M, Giordano L, Pantangelo A, D’Onofrio B, Villari G (2006). Effects of different levels of nitrogen fertilization on yield and fruit quality in processing tomato. Acta Horticulturae 700:129-132. https://doi.org/10.17660/ActaHortic.2006.700.19

Pourranjbari Saghaiesh S, Souri MK (2018). Root growth characteristics of Khatouni melon seedlings as affected by potassium nutrition. Acta Scientiarum Polonorum Hortorum Cultus 17(5):191-198. https://doi.org/10.24326/asphc.2018.5.17

Prudent M, Causse M, Génard M, Tripodi P, Granadillo S, Bertin N (2009). Genetic and physiological analysis of tomato fruit weight and composition: influence of carbon availability on QTL detection. Journal of Experimental Botany 60(3):923-937. https://doi.org/10.1093/jxb/ern338

Rajasree G, Pillai GR (2012). Effect of nitrogen nutrition on fruit quality and shelf life of cucurbitaceous vegetable bitter gourd. Journal of Plant Nutrition 35(8):1139-1153. https://doi.org/10.1080/01904167.2012.676127

Ramírez SLF, Díaz SFR, Muro EJ (2012). Relation between soilless tomato quality and potassium concentration in nutritive solution. Acta Horticulturae 947:215-221. https://doi.org/10.17660/ActaHortic.2012.947.26

San Martín-Hernández C, Ordaz-Chaparro VM, Sánchez-García P, Colinas-León MTB, Borges-Gómez L (2012). Tomato (Solanum lycopersicum L.) quality produced in hydroponics with different particle sizes of tezontle. Agrociencia 46(3):243-254.

SAS Institute Inc. (2011). SAS/STAT Users Guide. Version 9.3. SAS Institute Inc., Cary, N. C., USA.

Souri MK, Dehnavard S (2017). Characterization of tomato growth and fruit quality under foliar ammonium sprays. Open Agriculture 2(1):531-536. https://doi.org/10.1515/opag-2017-0055

Souri MK, Dehnavard S (2018) Tomato plant growth, leaf nutrient concentrations and fruit quality under nitrogen foliar applications. Advances in Horticultural Science 32(1):41-47. https://doi.org/10.13128/ahs-21894

Souri MK, Hatamian M (2019). Aminochelates in plant nutrition; a review. Journal of Plant Nutrition 42(1):67-78. https://doi.org/10.1080/01904167.2018.1549671

Souri MK, Rashidi M, Kianmehr MH (2018). Effects of manure-based urea pellets on growth, yield, and nitrate content in coriander, garden cress, and parsley plants. Journal of Plant Nutrition 41(11):1405-1413. https://doi.org/10.1080/01904167.2018.1454471

Souri MK, Sooraki FY, Moghadamyar M (2017). Growth and quality of cucumber, tomato, and green bean under foliar and soil applications of an aminochelate fertilizer. Horticulture, Environment, and Biotechnology 58(6):530536. https://doi.org/10.1007/s13580-017-0349-0

Steiner AA (1961). A universal method for preparing nutrient solutions of a certain desired composition. Plant and Soil 15:134-154. http://dx.doi.org/10.1007/BF01347224

Taber H, Perkins-Veazie P, Li S, White W, Rodermel S, Xu Y (2008). Enhancement of tomato fruit lycopene by potassium is cultivar dependent. HortScience 43(1):159-165. https://doi.org/10.21273/HORTSCI.43.1.159

Tang G (2010). Bioconversion of dietary provitamin A carotenoids to vitamin A in humans. The American Journal of Clinical Nutrition 91(5):1468S-1473S. https://doi.org/10.3945/ajcn.2010.28674G

Tohidloo G, Souri MK, Eskandarpour S (2018). Growth and fruit biochemical characteristics of three strawberry genotypes under different potassium concentrations of nutrient solution. Open Agriculture 3:356-362. https://doi.org/10.1515/opag-2018-0039

Vasák M, Schnabl J (2016). Sodium and potassium ions in proteins and enzyme catalysis. In: Sigel A, Sigel H, Sigel RKO (Eds). The Alkali Metal Ions: Their Role for Life. Metal Ions in Life Sciences. Springer, Cham, Switzerland, pp 259-290. https://doi.org/10.1007/978-3-319-21756-7_8

Vicente AR, Manganaris GA, Ortiz CM, Sozzi GO, Crisosto CH (2014). Nutritional quality of fruits and vegetables. In: Florkowski WJ, Shewfelt RL, Brueckner B, Prussia SE (Eds). Postharvest Handling: A System Approach. Academic Press (3rd ed), San Diego, CA pp 69-122.

Wang C, Gu F, Chen J, Yang H, Jiang J, Du T, Zhang J (2015). Assessing the response of yield and comprehensive fruit quality of tomato grown in greenhouse to deficit irrigation and nitrogen application strategies. Agricultural Water Management 161:9-19. http://dx.doi.org/10.1016/j.agwat.2015.07.010

Wang M, Shen Q, Xu G, Guo S (2014). New insight into the strategy for nitrogen metabolism in plant cells. International Review of Cell and Molecular Biology 310:1-37. https://doi.org/10.1016/B978-0-12-800180-6.00001-3

Wang M, Zheng Q, Shen Q, Guo S (2013). The critical role of potassium in plant stress response. International Journal of Molecular Sciences 14(4):7370-7390. https://doi.org/10.3390/ijms 14047370 
San Martín-Hernández C, Gómez-Merino FC et al. (2021). Not Bot Horti Agrobo 49(2):12320

Witham FH, Blaydes DF, Devlin RM (1971). Experiments in plant physiology. Van Nostrand Reinhold Co. New York, USA.

Yilmaz E (2001). The chemistry of fresh tomato flavor. Turkish Journal of Agriculture and Forestry 25:149-155.

OPEN ACCESS

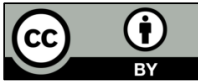

The journal offers free, immediate, and unrestricted access to peer-reviewed research and scholarly work. Users are allowed to read, download, copy, distribute, print, search, or link to the full texts of the articles, or use them for any other lawful purpose, without asking prior permission from the publisher or the author.

License - Articles published in Notulae Botanicae Horti Agrobotanici Cluj-Napoca are Open-Access, distributed under the terms and conditions of the Creative Commons Attribution (CC BY 4.0) License.

(C) Articles by the authors; UASVM, Cluj-Napoca, Romania. The journal allows the author(s) to hold the copyright/to retain publishing rights without restriction. 